All our patients had secondary hyperparathyroidism. Some may also have had osteomalacia, but bone biopsies were not performed to establish this. In microgram doses $1-x-\mathrm{OHD}_{3}$ proved very effective and was capable of increasing plasma calcium and phosphorus concentrations and decreasing plasma alkaline phosphatase and serum parathyroid hormone concentrations. An increase in plasma calcium was expected but some of the other changes merit further consideration.

The increase in the plasma phosphorus concentration was not due to any reduction in the intake of aluminium hydroxide. Neither was it likely to have been due to the renal consequences of parathyroid hormone suppression, for our patients were effectively anuric. It probably resulted from increased intestinal phosphorus absorption caused by $1-x-\mathrm{OHD}_{3}$. Starting treatment or increasing the dose of $1-x-\mathrm{OHD}_{3}$ often increased the plasma alkaline phosphatase concentration, which subsided within a month. A similar "flare" is common in other forms of osteomalacia or rickets treated with vitamin $\mathrm{D}$ and does not indicate treatment failure.

The reduction in serum parathyroid hormone concentration, which fell to normal in over half the patients, was striking. It was accompanied by improvement and often disappearance of radiological phalangeal erosive changes attributable to hyperparathyroidism. We cannot be certain that the osteomalacic component of our patients' osteodystrophy responded so well. It has been suggested that the osteomalacic component is more resistant to treatment with $1-x-\mathrm{OHD}_{3} .{ }^{1 "}$ The mechanism whereby circulating parathyroid hormone was reduced is unknown. In general there was a rise in plasma calcium, which may have inhibited secretion of parathyroid hormone. Hypercalcaemia itself, however, was not essential for the fall of parathyroid hormone concentration. In one patient the serum parathyroid hormone concentration fell, even though the plasma calcium concentration rose only slightly and remained within the normal range. In another patient serum parathyroid hormone and plasma alkaline phosphatase concentrations fell progressively without any detectable change in the plasma calcium concentration, which remained normal during the study. Therefore a derivative of vitamin $\mathrm{D}$ may directly suppress secretion of parathyroid hormone by the parathyroid glands.

The effect of $1-x-\mathrm{OHD}_{3}$ on parathyroid activity and bone appears to be slow and the response to treatment must be assessed over at least several months. It has been suggested that $1-x-\mathrm{OHD}_{3}$ is safer to use than the natural compound 1,25$(\mathrm{OH})_{2} \mathrm{D}_{3}$ since it is hydroxylated in the liver. In animals this step appears to be inhibited by the product of hydroxylation itself and may act as a potential safety factor.

Episodes of severe hypercalcaemia requiring a reduction of dose or temporary cessation of treatment occurred in six patients. In three the hypercalcaemia was associated with pruritus but with no other serious effects, and, in particular, radiologically detectable ectopic calcification was not produced. Hypercalcaemia was most likely to occur when renal osteodystrophy had improved, as shown by a fall in plasma alkaline phosphatase, radiological improvement, and a return of parathyroid hormone concentrations to near normal. It might, however, develop at any time during treatment with $1-\alpha-\mathrm{OHD}_{3}$, irrespective of the dose given, and careful monitoring of plasma calcium is therefore essential.

We thank Professor B Lythgoe and Leo Laboratories Ltd, for the supply of $1-x-\mathrm{OHD}_{3}$; the London Hospital Medical College and the National Kidney Research Fund for financial assistance; and the nursing staff of Hanbury dialysis unit and Miss A Ullathorne for their help.

Requests for reprints should be addressed to Dr A M Brownjohn, Department of Nephrology, London Hospital, London E1 $1 \mathrm{BB}$.

\section{References}

${ }^{1}$ Haussler, $\mathrm{M} \mathrm{R}$, in Vitamin D and Problems related to Uremic Bone Disease, ed A W Norman, et al. Berlin, Walter de Grayter, 1975.

- Catto, G R D, et al, British Medical fournal, 1975, 1, 12.

${ }^{3}$ Junor, B J R, et al, Proceedings of the European Dialysis and Transplant Association, 1976, 13, 424.

${ }^{4}$ Pierides, A M, et al, Lancet, 1976, 2, 1092.

5 Berry, E M, et al, British Medical fournal, 1973, 4, 640.

Addison, G M, et al, fournal of Endocrinology, 1971, 49, 521.

- Mawer, E B, et al, Lancet, 1973, 1, 626.

* Haussler, M R, et al, Clinical Endocrinology, 1976, 5, suppl, p 151.

${ }^{9}$ Bordier, P J, et al, Clinical Science, 1973, 44, 33.

10 Pierides, A M, et al, Lancet, 1976, 2, 1092.

\title{
Enhanced allergic tissue injury in Goodpasture's syndrome by intercurrent bacterial infection
}

\author{
A J REES, C M LOCKWOOD, D K PETERS
}

British Medical fournal, 1977, 2, 723-726

\section{Summary}

Studies of 16 relapses in seven patients receiving treatment for Goodpasture's syndrome showed that intercurrent bacterial infection seemed to be the precipitating event in 13 cases, whereas a rising antibody titre to glomerular basement membrane was responsible in only one.

Royal Postgraduate Medical School, London W12

A J REES, MRCP, senior registrar

C M LOCKWOOD, MRCP, MRC, research fellow

$D \mathrm{~K}$ PETERS, FRCP, reader in medicine
This association between infection and relapse in Goodpasture's syndrome has several implications for the pathogenesis of antibody-mediated tissue damage, and, clearly, more experiments are needed. Whatever the explanation, however, prevention and early diagnosis and treatment of infection in anti-GBM disease are important.

\section{Introduction}

We have recently developed a regimen of intensive plasma exchange and cytotoxic drugs for treating Goodpasture's syndrome associated with antibody to glomerular basement membrane $(G B M),{ }^{1}$ and this has provided an opportunity to study an unusually large number of patients. An important feature of this project has been monitoring disease by serial 
measurements of anti-GBM antibody using a sensitive and quantitative radioimmunoassay. ${ }^{2}$ In the course of this work we have observed that relapses of the disease in the kidneys and lungs were only exceptionally associated with a rise in anti-GBM antibody titres but were often related to the onset of intercurrent bacterial infection. Our purpose here is to record this phenomenon and to discuss the possible mechanisms.

\section{Patients and methods}

Sixteen patients with nephritis, serum anti-GBM antibodies, and linear staining of the GBM were studied. Fifteen also had pulmonary haemorrhage (Goodpasture's syndrome), and seven of these were anuric on presentation. All patients were treated with the regimen of immunosuppressive drugs and plasma exchange. ${ }^{1}$ After the introduction of this regimen titres of circulating antibody to GBM fell in every patient, pulmonary haemorrhage was controlled in 12 out of 13 , and renal function stabilised or improved in the nine with residual function. None of the seven anuric patients regained useful renal function. Despite early control, seven patients relapsed on 16 occasions; these relapses provide the basis for this report.

Investigations-Renal biopsies were performed and the specimens processed as described. ${ }^{3}$ Anti-GBM antibody was shown in serum by radioimmunoassay. ${ }^{2}$ Serial samples were assayed in all patients and the results correlated with disease activity. Circulating immune complexes were measured in patients by a radiolabelled Clq binding assay. ${ }^{4} \mathrm{C}$-reactive protein was measured by radial immunodiffusion ${ }^{5}$ using monospecific antiserum. Values were expressed on an arbitrary scale as a percentage of a reference specimen containing a high concentration of CRP. CRP is undetectable in normal sera in this assay.

Disease activity-Glomerular disease was considered active if either macroscopic or microscopic haematuria was present or if deteriorating renal function was shown by serial measurements of plasma creatinine or creatinine clearance. Lung disease was considered active if there was pulmonary haemorrhage as indicated by at least two of the following criteria: fresh haemoptysis, increased shadowing of the radiograph, a rise of over $40 \%$ in the carbon monoxide transfer factor $(\mathrm{kCO}){ }^{6}$ or an otherwise unexplained fall in haemoglobin of more than $2 \mathrm{~g} / \mathrm{dl}$ in 24 hours.

\section{Results}

Relapses were diagnosed on 16 occasions in seven patients: two patients had four relapses; one patient had three; one patient had two; and the remainder had one each (table I). On 10 occasions when relapse occurred in patients with residual renal function kidneys and lungs were affected simultaneously.

Only one relapse was associated with a rising titre of anti-GBM antibody; this patient (case 2) had originally developed pulmonary haemorrhage shortly after being established on a regular dialysis programme after presentation with anuric crescentic nephritis. At this stage the anti-GBM antibody titre was very high $(21 \%$ normal binding less than $1 \%$; see ref 1 ). After treatment with the plasma exchange regimen antibody titre fell to $5 \%$ and exchanges were stopped. During the next three weeks the titre rose progressively to $17 \%$, when minor pulmonary haemorrhage recurred.

Thirteen of the remaining 15 relapses were associated with intercurrent infection. This affected the arteriovenous shunt on seven occasions and the peritoneum, chest, pharynx, middle ear, urinary tract, and a bovine graft arteriovenous fistula once each. The organisms are shown in table I. Relapse was detected within 24 hours of the development of these infections, which were always accompanied by fever. Anti-GBM antibody titres were falling or were stable at values previously not accompanied by active disease and in only two was the value near that recorded at presentation. (At presentation none of the patients in this group had evidence of infection.) Circulating immune complexes were not found in the two patients in whom they were sought during relapse. A typical example of infection-related relapse is shown in fig 1 .

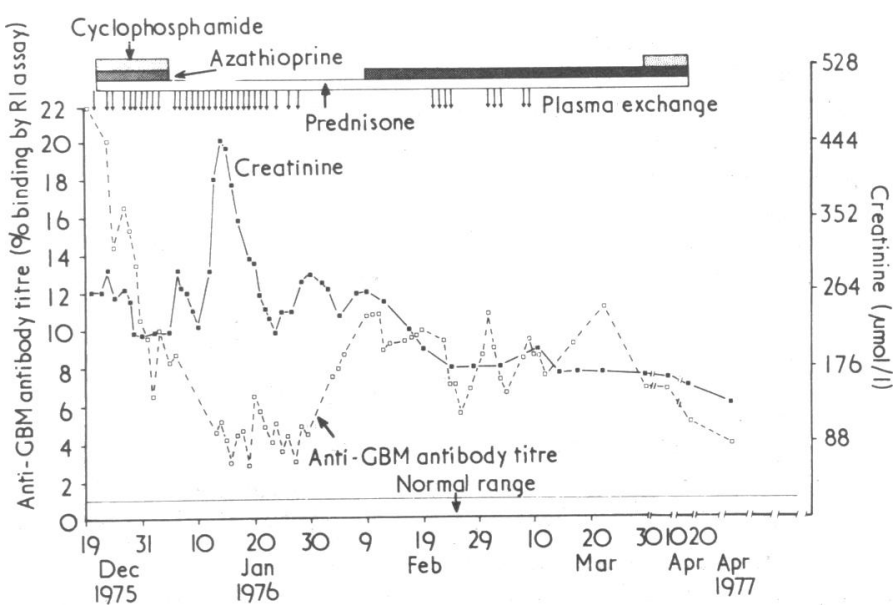

FIG 1-Case 3. Serial measurements of serum creatinine and anti-GBM antibodies. $\mathrm{ml}$

Conversion: SI to traditional units-Creatinine: $1 \mu \mathrm{mol} / 1 \approx 0.0113 \mathrm{mg} / 100$

Two relapses were detected in the absence of diagnosed infection in the same anuric patient (case 7) and were associated with fluid overload.

Five episodes of infection in three patients were not associated with relapse (table II), and in four titres of anti-GBM antibody were normal at this stage.

\section{Discussion}

Our observation that intercurrent infection enhances antibodymediated injury in the glomerular and lung basement membranes raises questions about the mechanism of allergic tissue damage

TABLE I-Relapses in Goodpasture's syndrome

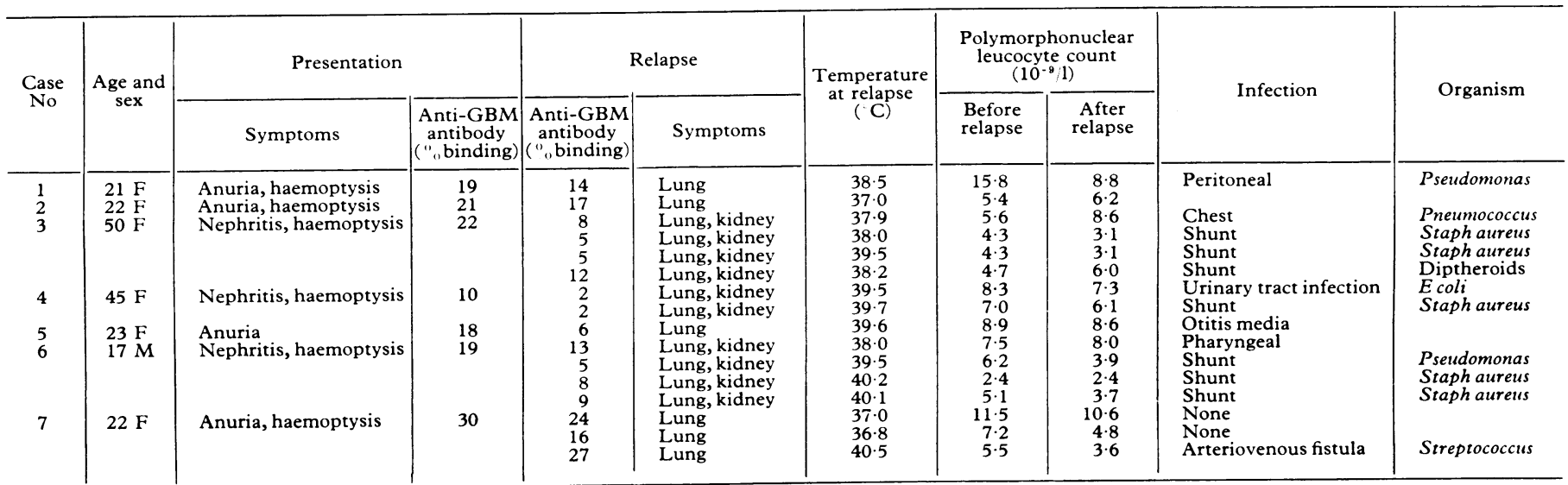


TABLE II-Infections without relapse in Goodpasture's syndrome

\begin{tabular}{|c|c|c|c|c|c|c|c|c|c|}
\hline \multirow{2}{*}{$\begin{array}{l}\text { Case } \\
\text { No }\end{array}$} & \multirow{2}{*}{$\begin{array}{l}\text { Age and } \\
\text { sex }\end{array}$} & \multicolumn{2}{|c|}{ Presentation } & \multicolumn{2}{|r|}{ Infection } & \multirow{2}{*}{ Temperature } & \multicolumn{2}{|c|}{$\begin{array}{l}\text { Polymorphonuclear } \\
\text { leucocyte count } \\
\left(10^{-9} / 1\right)\end{array}$} & \multirow{2}{*}{ Organism } \\
\hline & & Symptoms & $\begin{array}{l}\text { Anti-GBM } \\
\text { antibody } \\
(\text { ("., binding) }\end{array}$ & $\begin{array}{l}\text { Anti-GBM } \\
\text { antibody } \\
(" \text {, binding) }\end{array}$ & Site or type of infection & & $\begin{array}{c}\text { Before } \\
\text { infection }\end{array}$ & $\begin{array}{c}\text { After } \\
\text { infection }\end{array}$ & \\
\hline 8 & $55 \mathrm{M}$ & Nephritis, haemoptysis & 6 & 1 & Shunt & $\begin{array}{l}39 \cdot 5 \\
37.8\end{array}$ & $7 \cdot 6$ & $4 \cdot 2$ & Staph aureus \\
\hline 9 & $56 \mathrm{M}$ & Nephritis & 3 & 0 & Viral pneumonitis (biopsied) & 39.0 & $\begin{array}{l}4 \cdot 5 \\
8 \cdot 5\end{array}$ & $\begin{array}{l}4.7 \\
4.9\end{array}$ & \\
\hline 10 & $55 \mathrm{M}$ & Haemoptysis, nephritis & 3 & $\begin{array}{l}0 \\
0\end{array}$ & $\begin{array}{l}\text { Urinary tract infection } \\
\text { Systemic viral infection }\end{array}$ & $\begin{array}{l}37 \cdot 5 \\
38 \cdot 8\end{array}$ & $\begin{array}{r}10.5 \\
9 \cdot 0\end{array}$ & $\begin{array}{r}7.7 \\
11.5\end{array}$ & E coli \\
\hline
\end{tabular}

that have wide implications in immunopathology. Transient worsening of renal function accompanied by haematuria is well recognised in patients with chronic glomerular diseases after non-specific insults such as physical exercise, surgery, inoculations, and pharyngeal infection. ${ }^{-9}$ This is most characteristically seen in mesangial IgA nephropathy ${ }^{10}$ but also occurs in other forms of nephritis such as membranoproliferative glomerulonephritis ${ }^{11}$ and focal nephritis not associated with $\operatorname{IgA}$ deposits. ${ }^{12}$ Intercurrent infection has also been reported to precipitate rejection of renal allografts. ${ }^{13} 14$ Nevertheless, our report seems to be the first to suggest that enhancement of tissue injury is independent of any change in the primary allergic insult - that is, the generation of antibody to GBM.

Extensive studies of an experimental model of nephritis induced by antibody to GBM have shown that the polymorphonuclear leucocytes have a central role in injury: animals depleted of circulating polymorphs by alkylating agents or antipolymorph sera were substantially protected ${ }^{1516}$ and repletion of such animals with fresh polymorphonuclear leucocytes caused injury (proteinuria) that was roughly proportional to the polymorph count. $^{1 \text {; }}$ We therefore considered whether an increase in polymorph count in response to infection might have been responsible for the enhanced injury in our patients, but this did not appear to be the case, for in only four of the 13 episodes was any increase observed, presumably because of cytotoxic treatment. The next question is whether some intrinsic change in the polymorph response to infection might be responsible. Studies in experimental nephritis suggest that the adherence of polymorphs to the capillary basement membrane depends on complement $(\mathrm{C} 3 \mathrm{~b})$ and $\mathrm{Fc}_{\mathrm{c}}$ receptors, which react with the bound immunoglobulin and complement, and injury is brought about by release of proteolytic enzymes. ${ }^{1 ; 1 \times}$

In-vitro exposure of polymorphs to minute doses of endotoxin stimulates phagocytosis, $19: 20$ increases the uptake of nitroblue tetrazolium, ${ }^{21}$ and enhances killing of staphylococci. ${ }^{20}$ Bacterial infection similarly results in raised nitroblue tetrazolium uptake, ${ }^{2 \cdot 2}$ and increased leucotactic response have been reported by Hill et al. ${ }^{23}$ In the case of the macrophage, infection increases bactericidal capacity and also results in an increase in $\mathrm{Fc}$ receptors on the cell surface ${ }^{24}{ }^{25}$; data on polymorphonuclear leucocyte $\mathrm{Fc}$ receptors during infection have not been reported.

The role of the acute phase response-the rapid increase in the concentration of various plasma proteins such as fibrinogen, C-reactive protein, and complement components that follows tissue injury-also has to be considered. Fibrin deposition is intimately concerned in inflammation and in the glomerulus with crescent formation. ${ }^{14} \mathrm{C}$-reactive protein has a range of activities of potential biological importance; these include initiation of complement consumption ${ }^{26} 27$ and promotion of phagocytosis. $^{28}$ Considerable increases of C-reactive protein levels were associated with infection and relapse in our patients (see fig 2).

The question whether complement itself might be implicated is also important. Earlier work indicated that complement played an important part in allergic glomerular inflammation by mediating binding of polymorphs to the basement membrane, ${ }^{15}$ but recent studies in animals have shown that polymorphdependent injury can occur in C3-depleted animals, probably
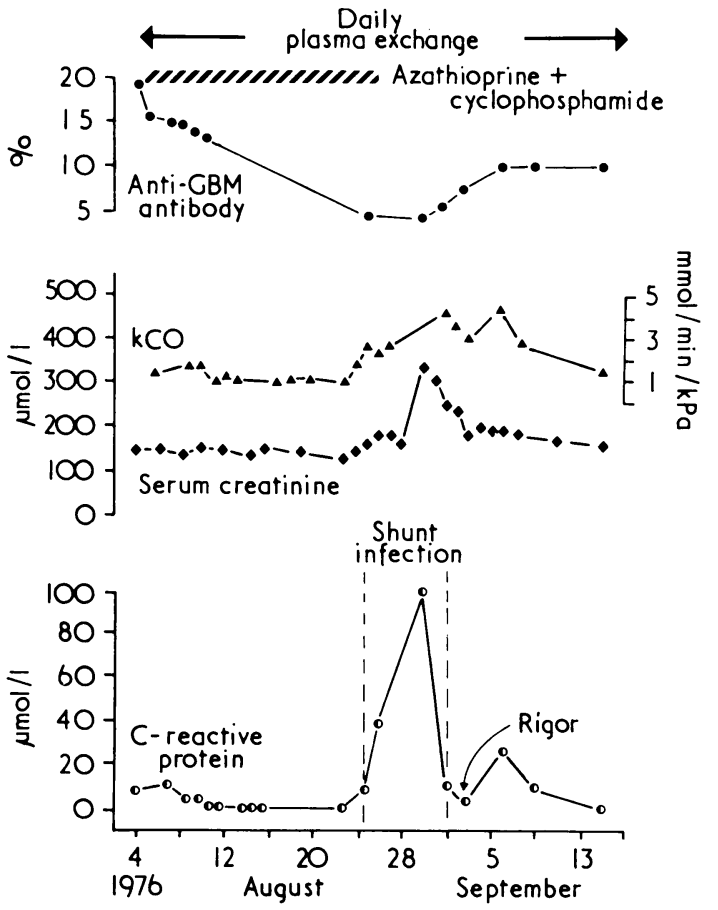

FIG 2-Case 6. Serial measurements of anti-GBM antibody titre, $\mathrm{kCO}$, serum creatinine, and C-reactive protein. (Anti-GBM antibody normal $<1 \%$; C-reactive protein normally undetectable.)

Conversion: SI to traditional units $-\mathrm{kCO}: 1 \mathrm{mmol} / \mathrm{min}$ $\mathrm{kPa} \approx 3.0 \mathrm{ml} / \mathrm{min} / \mathrm{mm} \mathrm{Hg}$.

because the adherence reaction can be efficiently brought about by IgG antibody alone, presumably through the Fc receptors. ${ }^{29}$ In six of our patients immunofluorescence studies showed no evidence of $\mathrm{C} 3$ deposition on the basement membrane, suggesting that this process of complement-independent injury was occurring in vivo.

It seems reasonable to suppose that these cellular and humoral responses to infection are of protective value and, though intrinsically non-specific, are specifically brought to bear on the infectious agent through immunological processes -in the case of antibody the engagement through Fc or Fcdependent reactions (such as complement fixation) of the various reticulophagocytic cells. When these infection-stimulated responses occur in the presence of a pathogenetic autoantibody, however, such as antibody to GBM, the processes that enhance elimination of infection might simultaneously be expected to worsen injury mediated by anti-GBM antibody.

Finally, a different explanation to consider is that infection leads to enhanced tissue damage through the superimposition of infection-derived immune complex disease. In animals small doses of antibody to GBM greatly facilitate glomerular localisation of circulating immune complexes. ${ }^{30}$ For what it is worth, we have failed to show circulating complexes in our patients, 
though the technique used (the polyethylene glycol precipitation of $\left.{ }^{1: 5} \mathrm{Clq}^{+}\right)$may have been insufficiently sensitive.

These interesting possibilities are open to experiment. Whatever the explanation the phenomenon is of considerable clinical importance and emphasises the need for prevention and early diagnosis and treatment of infection in anti-GBM disease. We suspect that reports describing the development of Goodpasture's syndrome after upper respiratory tract infection are also examples of the same type of phenomenon. ${ }^{31}$ 3: The extent to which similar events occur in other forms of allergic disease deserves study.

We should particularly like to acknowledge the help of Dr C B Wilson of the Scripps Clinic, La Jolla, for performing anti-GBM antibody assays for us. We also thank the physicians who referred patients to us and Miss Sally Gibbons and Mrs J MacAuley for expert technical help.

\section{References}

${ }^{1}$ Lockwood, C M, et al, Lancet, 1976, 1, 711

Wilson, C B, Marquardt, H, and Dixon, F J, Kidney International, 1974, 6, 114A.

${ }^{3}$ Evans, D J, et al, British Medical fournal, 1973, 3, 326.

Zubler, R H, et al, fournal of Immunology, 1976, 116, 232.

Mancini, G, Carbonara, A O, and Heremans, J F, Immunochemistry, $1965,2,235$.

${ }^{6}$ Ewan, P W, et al, New England fournal of Medicine, 1976, 295, 1391.

' Baehr, G, Fournal of the American Medical Association, 1926, 86, 1001.
${ }^{8}$ Bates, R C, Jennings, R B, and Earle, D P, American Fournal of Medicine, $1957,23,510$

${ }^{9}$ Ross, J H, Quarterly fournal of Medicine, 1960, 29, 391.

1" Berger, J, and Hinglais, N, Fournal of Urology and Nephrology, 1968, 74, 694

11 Vargas, R, et al, Clinical Nephrology, 1976, 5, 73.

1: Van de Putte, L B A, De la Riviere, G B, and Van Breda Vreisman, P J C, New England fournal of Medicine, 1974, 290, 1165.

13 Simmons, R L, et al, Transplantation Procéedings, 1970, 2, 419.

1 Briggs, J D, et al, British Medical fournal, 1972, 4, 520.

${ }^{15}$ Cochrane, C G, Unanue, E R, and Dixon, F J, fournal of Experimental Medicine, 1965, 122, 99.

${ }^{1{ }^{i}}$ Naish, P F, et al, Clinical and Experimental Immunology, 1975, 22, 102.

1: Henson, P M, American fournal of Pathology, 1972, 68, 593.

1* Cochrane, C G, Adrances in Immunology, 1968, 9, 97.

${ }^{19}$ Fritze, E, and Wendt, F, Klinische Wochenschrift, 1955, 33, 575.

"Cohn, Z A, and Morse, S I, fournal of Experimental Medicine, 1960, 111, 689.

21 Park, B H, and Good, R A, Lancet, 1970, 2, 616.

2: Park, B H, Filznig, S M, and Smithwick, E M, Lancet, 1968, 2, 532.

${ }^{23}$ Hill, H R, et al, fournal of Clinical Investigation, 1974, 53, 996.

${ }^{24}$ Atkinson, J P, and Frank, M M, fournal of Clinical Investigation, 1974 53,1742 .

${ }^{25}$ Arend, W P, and Mannik, M, fournal of Immunology, 1973, 110, 1455.

${ }^{26}$ Kaplan, M H, and Volankis, J E, Fournal of Immunology, 1974, 112, 2135.

2: Siegel, J, Rent, R, and Gewurz, H, fournal of Experimental Medicine, $1974,140,631$.

2* Kindmark, C O, Clinical and Experimental Immunology, 1971, 8, 941.

29 Thomson, N M, et al, Clinical and Experimental Immunology, 1976, 24, 464.

${ }^{30}$ Mauer, M S, et al, fournal of Clinical Investigation, 1974, 53, 931.

${ }^{31}$ Benoit, F L, et al, American fournal of Medicine, 1964, 37, 424.

2 Wilson, C B, and Smith, R C, Annals of Internal Medicine, 1972, 76, 91.

\section{Summary}

The most serious adverse effect of standard intestinal bypass for obesity is the high incidence of hepatic dysfunction and death from hepatic failure. We therefore examined the long-term effects of a modified form of jejunoileal bypass (in which a greater continuous length of ileum is retained), on liver function in 120 patients.

Substantial weight loss $(119.0$ SD $23.3 \mathrm{~kg}$ to $82.3 \div 18.8$ $\mathrm{kg}$ ) occurred during the first nine months after surgery, accompanied by a significant rise in serum concentrations of bilirubin, alanine transferase, and alkaline phosphatase, and a significant reduction in albumin concentrations. Biochemical changes were unrelated to weight loss or halothane anaesthesia. After weight stabilisation liver function reverted to normal, and four years after

Departments of Medicine, Surgery, and Histopathology, St George's Hospital Medical School, London SW17 0RE

J D MAXWELL, MB, MRCP, senior lecturer in medicine

ISABEL SANDERSON, MB, MRCP, senior medical registrar

W H BUTLER, MB, MRCPATH, senior lecturer in histopathology

J C GAZET, MS, FRCS, consultant surgeon

$T$ R E PILKINGTON, MD, FRCP, professor of medicine bypass sulphobromophthalein retention and hepatic histology did not differ from those in obese controls. There were two postoperative deaths. Three other patients died during the period of rapid weight loss with severe hepatic steatosis.

While transient mild impairment of liver function is common after modified jejunoileal bypass, clinically significant hepatic dysfunction is a rare and unexplained early complication.

\section{Introduction}

Obesity, the major nutritional disorder in affluent western societies, is an increasingly important health hazard. Unfortunately, its correction has proved to be a formidable problem as medical measures provide only temporary relief. Thus surgical management is an appropriate consideration for selected patients with gross obesity who have failed to lose weight under strict medical supervision.

Various intestinal bypass procedures have been used to achieve weight reduction. The first operation introduced, jejunocolic bypass, has now been abandoned because of its unacceptably high morbidity and mortality, and replaced by jejunoileal bypass. The standard operation of Payne and De Wind, ${ }^{1}$ in which $35 \mathrm{~cm}$ (14 inches) of proximal jejunum is anastomosed to $10 \mathrm{~cm}$ ( 4 inches) of terminal ileum, has undoubtedly proved effective, and produces substantial weight loss accompanied by gratifying psychosocial improvement." 